\title{
REVIEW
}

\section{Electrofishing as a potential threat to freshwater cetaceans}

\author{
Peter O. Thomas ${ }^{1, *}$, Frances M. D. Gulland ${ }^{1}$, Randall R. Reeves ${ }^{2}$, Danielle Kreb ${ }^{3}$, \\ Wang Ding ${ }^{4}$, Brian Smith ${ }^{5}$, Muhammad Imran Malik ${ }^{6}$, Gerard E. Ryan ${ }^{7}$, Somany Phay ${ }^{8}$ \\ ${ }^{1}$ Marine Mammal Commission, 4340 East-West Highway, Bethesda, Maryland 20814, USA \\ ${ }^{2}$ Okapi Wildlife Associates, 27 Chandler Lane, Hudson, Quebec J0P1H0, Canada \\ ${ }^{3}$ Yayasan Konservasi Rasi, Komplek Pandan Harum Indah, Samarinda, 75124 Kalimantan Timur, Indonesia \\ ${ }^{4}$ Institute of Hydrobiology, The Chinese Academy of Sciences, Wuhan, Hubei 430072, PR China \\ ${ }^{5}$ Wildlife Conservation Society, Asian Coastal Cetacean Program, IUCN SSC Cetacean Specialist Group, Arcata, \\ California 95518, USA \\ ${ }^{6}$ Indus River Dolphin Conservation Project (IRDCP), WWF-Pakistan, Sukkur 65310, Pakistan \\ ${ }^{7}$ School of BioSciences, University of Melbourne, Melbourne, Victoria 3052, Australia \\ ${ }^{8}$ WWFund Cambodia, \#21, St. 322, Boeung Keng Kang I, Chamkar Morn, Phnom Penh 12300, Cambodia
}

\begin{abstract}
Electrofishing is an accepted practice for legal fish sampling and surveying, but its use for subsistence food and market fishing has long been illegal in most countries. Illegal use affects freshwater fish populations in many parts of the world, and has been cited as a cause of mortality for endangered freshwater cetaceans in China (Yangtze dolphins and finless porpoises) and Southeast Asia (Ayeyarwady, Mekong, and Mahakam dolphins in Myanmar, Cambodia, and Indonesia, respectively), although the extent of this threat to cetaceans is unclear. Given their threatened status, these populations can ill afford such mortality in addition to the other threats they face (e.g. entanglement in gillnets, habitat deterioration and loss, declines in prey). Here, we review the evidence that electrofishing is a serious threat to freshwater cetaceans. It may alter the behavior of dolphins and porpoises, and contact with electrical currents may even directly kill or injure these animals, although questions remain unanswered concerning the exact nature and scale of the impacts. While other threats may appear more certain and urgent, electrofishing could be playing a significant role in driving the declines of some critically endangered freshwater cetaceans in Asia. Due to ethical and logistical challenges to improving our understanding of the impacts of electrical currents on cetaceans, clear descriptions of lesions in dead animals found stranded are needed to characterize the damage caused by electrofishing, to be more certain about cause and effect beyond spatiotemporal associations, and to determine the extent of this threat. Mortality from electrofishing seems to be uncommon, but in face of the uncertainties and the numerous other threats to these small populations, high priority should be given to enforcing electrofishing bans in the freshwater habitat of dolphins and finless porpoises.
\end{abstract}

KEY WORDS: Freshwater cetaceans $\cdot$ River dolphins $\cdot$ Finless porpoises $\cdot$ Electrofishing $\cdot$ Cetacean conservation

\section{INTRODUCTION}

Several species of cetaceans occur solely or partly in freshwater systems of South America (Amazon, Orinoco, Tocantins/Araguaia, Madeira), southern Asia (Indus, Ganges, Brahmaputra, Karnaphuli), Southeast

*Corresponding author: pthomas@mmc.gov
Asia (Ayeyarwady, Mekong, Mahakam), and East Asia (Yangtze), and many of these populations are endangered. The Amazon River dolphin Inia geoffrensis is endemic to the 4 aforementioned South American river systems and was recently Red-Listed by the IUCN as Endangered (da Silva et al. 2018a). The tucuxi Sotalia

(C) The authors 2019. Open Access under Creative Commons by Attribution Licence. Use, distribution and reproduction are unrestricted. Authors and original publication must be credited. 
fluviatilis, which is endemic to the Amazon system, is currently listed as Data Deficient (Secchi 2012) but urgently needs reassessment as its conservation status has deteriorated rapidly in recent years, at least in Brazil (da Silva et al. 2018b). The South Asian river dolphin Platanista gangetica is Endangered (Braulik \& Smith 2017), with 2 subspecies (both Endangered): the bhulan P. g. minor in the Indus system (Braulik et al. 2012) and the susu P. g. gangetica in the Ganges, Brahmaputra, and Karnaphuli systems (Smith et al. 2012). The Irrawaddy dolphin Orcaella brevirostris, an Endangered and primarily coastal marine species (Minton et al. 2017), has 3 entirely freshwater subpopulations, all of them Red-Listed as Critically Endangered - one in the Ayeyarwady of Myanmar (Smith 2004), one in the Mekong of Cambodia and Laos (Smith \& Beasley 2004), and one in the Mahakam of Indonesia (Jefferson et al. 2008). Finally, 2 freshwater cetaceans historically inhabited the Yangtze River and adjoining Dongting and Poyang lakes. The Yangtze River dolphin, or baiji Lipotes vexillifer, continues to be RedListed as Critically Endangered (possibly Extinct), but it has been at least functionally extinct since the early $21^{\text {st }}$ century (Smith et al. 2017). The Yangtze finless porpoise, a subspecies of the Endangered narrowridged finless porpoise Neophocaena asiaeorientalis (Wang \& Reeves 2017), is Red-Listed as Critically Endangered (Wang et al. 2013).

All freshwater cetaceans face numerous types and degrees of anthropogenic threats, and their threatened state is, in every case, due to multiple factors - the vast majority of which are being driven by human action, whether deliberate or incidental. The primary factors threatening their survival are direct injury and mortality in legal and illegal fisheries (e.g. entanglement in gear, deliberate retaliation to protect gear and catch from depredation); deliberate hunting to obtain fish bait (particularly for the Amazon River dolphin), and loss and fragmentation of cetacean and prey habitat due to water development projects (e.g. dams and barrages, embankments, conversion of wetlands). Additional threats in some areas include vessel traffic (e.g. dredging, noise, boat strikes), harbor construction (e.g. noise, land reclamation for infrastructure), and exposure to contaminants (e.g. from industrial effluent, urban and agricultural runoff, gold mining).

The focus of this paper is on a specific form of fishing - electrofishing — that has been characterized, but not well-documented or well-described, as a serious threat to some freshwater cetacean populations in Asia. Electrofishing has not (yet) been identified as a threat to freshwater cetaceans in South America (Secchi 2012, da Silva et al. 2018a).
Our objectives were four-fold: (1) to explain what electrofishing is and how it might be expected to affect cetaceans; (2) to summarize available evidence concerning mortality as well as responses of the animals to exposure; (3) to critically evaluate such evidence; and (4) to identify gaps in our understanding of how electrofishing threatens freshwater cetaceans.

\section{INFORMATION SOURCES AND METHODS}

Information on the mechanics and physics of electrofishing was obtained by requesting advice from experts on the subject who work (or worked) with the US Fish and Wildlife Service (Alan Temple and Jan Dean) and by reviewing manuals and publications on its use and the potential hazard it poses to mammals, including humans.

All the authors of this paper have field experience with freshwater cetaceans and have participated in conferences, workshops, and informal discussions with fishermen, fishery managers, and government officials in the range countries. Some of us have observed electrofishing in the vicinity of dolphins or porpoises, some have examined dead cetaceans that were thought to have died of electrocution, and some have seen electrofishing equipment deployed in areas inhabited by cetaceans. As a result, much of the information in this paper, as well as many of the ideas discussed and the conclusions reached, come from direct experience.

In addition, we canvassed colleagues in the various range countries to determine where electrofishing does and does not occur and to obtain as much detail as possible regarding spatial and temporal overlap with dolphins and porpoises. This included an initial informal questionnaire to researchers in Cambodia, Myanmar, Indonesia, and China to identify concerns, equipment used, and perspectives on the nature of effects of electrofishing on freshwater cetaceans. Wherever we found reference to mortality of cetaceans attributed to electrofishing in the literature or media outlets, we made an effort to follow this up with the original source or sources to learn more about the circumstances and how causation was diagnosed.

\section{RESULTS}

\subsection{Electrofishing}

\subsubsection{What it means}

Electrofishing is an important and commonly used tool that allows fish biologists to collect a variety of 
data in the field, e.g. to assess species composition, estimate populations and growth rates, and collect individual fish for analysis (Bohlin et al. 1989, Snyder 2003). Generally, legal electrofishing for scientific purposes is not intended to kill fish but to stun them so that they can be counted or so that individuals or samples can be collected. When used for fish sampling, the type, power, and form of the electrical current are adjusted, and the size and shape of anodes are designed to reduce or eliminate the likelihood of fish being injured or killed by the electrical current (Kolz 1989).

\subsubsection{How it works}

A basic manual (www.efish-solutions.com/support/ library-intro/) describes electrofishing as:

the process of using electricity to catch fish by creating an electrical-field through water, around an anode (usually on a hand-held pole or hanging from a boat) and cathode (trailing in the water behind the operator or boat). The electric-field between the 2 electrodes develops a voltage along the length of fish exposed to it, such that galvanotaxis stimulates their nervous system, and they swim 'up current' towards the anode (the source of the field). At a point approaching the source of the field, the fish enter a zone where the field is then of sufficient strength to temporarily immobilize them and thus aid in their capture.

Electrofishing manuals define 3 primary zones of influence around the electrodes based on fish behavior and physiological/muscular response to electrical fields, the dimensions of which depend upon the voltage used and the conductivity of the environment. The 'zone of detection' (or 'perception') is the portion of the electrical field where the fish is aware of it but can move away; the 'effective zone' (for fish capture) is where fish may be forced to swim toward the electrode and become immobilized but are not harmed; and the 'injury zone' is where fish experience such high voltage gradients and power (and current) densities that they are injured or killed ( $\mathrm{J}$. Dean pers. comm.). Understanding these zones and the equipment and electrical currents used to create them provides the operational basis for capturing fish. For boat-mounted equipment, the effective zone typically has a radius of $2-3 \mathrm{~m}$.

The voltages required to immobilize fish of different sizes and types have been carefully studied, although many details of the effects on fish are still uncertain. In general, larger fish (in terms of total body surface area) are more likely to be paralyzed or injured (spinal injuries from sudden muscular contractions), and thus are more easily captured than smaller ones, because larger size allows a larger voltage difference to develop across the body (Emery 1984, Mahoney et al. 1993, Dalbey et al. 1996, Dolan \& Miranda 2003, Snyder 2003). Thin-scaled and unscaled fishes, including large catfishes, are less resistant to electrical currents than are thick-scaled fishes (Green 2011).

Electrofishing gear is generally powered by DC batteries (carried in backpack units) or small generators on boats. The need for mobility usually limits the size of the power supply and the amount of power that can be applied in the water (Mahoney et al. 1993, Reynolds \& Harlan 2011).

\subsubsection{How it could affect cetaceans}

Cetaceans could be injured or killed directly by electrofishing when they come into (1) direct contact with the electrodes, thus becoming part of the electrical circuit or (2) contact with the electrical fields produced in the water by electrofishing devices. The impact of a given electrical field depends on the distance of an animal from the source and the nature of the field itself.

There is no question that direct contact with electrodes in water is potentially fatal for mammals of all sizes. For example, when an animal makes physical contact with a metal electrode, whether accidentally or deliberately (e.g. out of curiosity), it becomes "directly "wired" to the power source and is subject to possible electrocution' (Kolz \& Johnson 1995, p. 211). Large-scale experiments with electric harpoons in the 1930s proved this in a dramatic manner with blue whales Balaenoptera musculus (Mitchell 1986). The prototypes used in field trials under the auspices of the Norwegian Association of Whaling Companies proved extremely effective, paralyzing the whales and causing them to roll over onto their sides with flippers and flukes above water. It reportedly did not matter where the whale was hit - the result was usually a rapid death. Although the 'killing current' was $220 \mathrm{~V} 50 \mathrm{~Hz}$ AC, resistance was so low that on average a potential of $20 \mathrm{~V}$ passing through the body was claimed to be sufficient for killing these large creatures.

Electrocution, cardio-respiratory failure, and drowning can also be the fate of fishermen who make mistakes when using electrofishing equipment (Di Nunno et al. 2003). In descriptions of potential human injury from electrofishing it is often difficult to discern whether authors are referring to direct physical contact with electrical circuits or with electrical fields, 
but the vulnerability is clear, regardless. Reynolds \& Kolz (2013, p. 337), for example, confirmed that the batteries and generators used in electrofishing as practiced for scientific fish monitoring deliver 'more than enough energy to electrocute a person.' They note that grasping a wire carrying as little as $0.01 \mathrm{~A}$ can cause muscular tetany and inability to release one's grip, leading to death from respiratory arrest, asphyxia, or ventricular fibrillation. Primavesi (2009) emphasized that in human electrical injuries, skin thickness and moisture are crucial factors because skin resistance impedes current flow and protects against electrocution.

There is greater uncertainty about the harm that could come to freshwater cetaceans when they come into contact with the electrical fields in the water produced by electrofishing devices. Fish behavior and size, water conductivity and temperature, substrate, and current strength are among the well-studied variables that influence the effectiveness of electrofishing (Emery 1984, Mahoney et al. 1993), but we have little knowledge of the behavioral, physiological, and neurological responses of cetaceans as they enter an electrically charged zone, or of the distances or voltages at which they would begin to detect it. Experienced electrofishing personnel reported that geese, ducks, beavers, muskrats, and nutrias did not appear to be 'inadvertently shocked at the power levels normally used for fish' (Kolz \& Johnson 1995, p. 208).

Pictures and descriptions of electrofishing equipment used by artisanal fishermen in the rivers and lakes of East and Southeast Asia do not suggest that the electrical outputs or effective distances produced would be of significantly greater magnitude than those produced by standard devices used for legal fish sampling elsewhere. There is no evidence of technological difference, other than the power of the electrical source, that would significantly increase the power and range of influence of such basic equipment or change the basic behavior of electrical fields. This leads electrofishing experts to discount general statements such as 'the lethal electric charge was able to kill anything within a range of 20 meters...' (Turvey 2008, p. 39), but the larger apparatus described as being used in the Yangtze River may have greater reach (A. Temple pers. comm.).

3.1.4. Sensitivity and response of freshwater cetaceans and other mammals to electrical fields

There are few descriptions of the behavior of small cetaceans or other aquatic mammals reacting to elec- trical fields. Research on dolphin electro-receptivity and pinniped deterrence indicates that some marine mammals can detect low-level electrical fields. Guiana dolphins Sotalia guianensis can easily detect lowlevel electrical fields produced by electric fish and have specialized sensory anatomy ('vibrissal crypts') for doing so (Czech-Damal et al. 2012). Deterrence experiments on California sea lions Zalophus californianus (Burger 2008) and harbor seals Phoca vitulina (Forrest et al. 2009) showed that pinnipeds detect and are actively deterred from weak electrical fields in freshwater environments. An expert in electrofishing (A. Temple pers. comm.) suggested that if free-swimming dolphins have the ability to detect extremely low electrical field strengths, they should be able to avoid entering the 'effective' and 'injury' zones. This assumes that they recognize the low electrical field strengths as a danger, and that they are as resistant as pinnipeds to them. Cetacean skin, however, is less keratinized and hairless, potentially increasing the electrical conductance of this external barrier in comparison with other mammals (Harrison \& Thurley 1974).

\subsubsection{Legal status of electrofishing}

Electrofishing is banned or restricted in most of the rivers and lakes where freshwater cetaceans occur in Asia (Table 1), but the economic incentives for its use are strong. In Cambodia, for example, legal fishing with a cast net (cost: USD \$10-12) yielded a fisherman 6-7 kg of small fish, or \$3-4 $\mathrm{d}^{-1}$ (Kurien 2007), whereas with a \$30-40 investment in illegal electrofishing equipment, an unskilled and untrained person could catch $20-30 \mathrm{~kg}$ of large fish worth \$10-13 $\mathrm{d}^{-1}$ and a skilled electro-fisherman could catch 30$40 \mathrm{~kg}$ in a single haul (Kurien 2007). The equipment for electrofishing is relatively inexpensive (and the battery can be used in the home for other purposes), little maintenance is required (unlike for nets, longlines, bamboo traps, and fishing fences which require constant repair), and relatively large catches can be made with little effort (Smith \& Tun 2007).

\subsubsection{Illegal electrofishing gear}

We have not found detailed technical descriptions of apparatus used for illegal electrofishing in the rivers of Asia, nor have we had the opportunity to examine such equipment, except through photos. Table 1 summarizes descriptions of electrofishing operations and apparatus that we found in fisheries 
reports and news accounts or obtained from the informal responses of researchers to our simple questionnaire.

\subsection{Impacts of electrofishing}

3.2.1. Impacts on prey species and the ecosystems of freshwater cetaceans

Like dynamite and poison fishing, electrofishing, if used without controls, is a potentially destructive and indiscriminate fishing method with lethal or sublethal impacts on both target and non-target species. The entire 'ecological footprint' of freshwater electrofishing falls outside established management regimes, catch limits, and other restrictions that might apply to legal fishing activity (Garcia et al. 2003, Kreb et al. 2007, Phen \& Nam 2011, FAO 2016).

In China, Zhou et al. (1998) reported that electrofishing, though 'strictly banned by the fishery agency,' was pursued at night, in small boats that hid during the day in small channels adjacent to the Yangtze River. In Myanmar, electrofishing is used illegally for commercial fishing on the Ayeyarwady River, reportedly with wide-ranging impacts on fish stocks and biodiversity, including riverine fish and turtles (https://www. mmtimes.com/news/working-save-symbol-humananimal-cooperation.html).

The presence of multiple illegal operators, sometimes working in organized gangs to avoid detection and intimidate enforcement officers, as occurs on the Ayeyarwady River, greatly increases the overall impact on fishery resources and aquatic biodiversity (Smith 2004, Smith \& Tun 2007, Holland 2015, http://news.nationalgeographic.com/news/2015/02/ 150217-irrawaddy-dolphins-myanmar-electro-fishingmandalay/).

\subsubsection{Behavioral impacts on freshwater cetaceans}

Interactions between fishermen and dolphins are likely because freshwater cetaceans generally feed in relatively confined and specific areas (e.g. deep pools, eddies, confluences) that are also prime fishing grounds exploited by fishermen using nets and lines as well as electricity.

In addition to prey depletion, reports from the Ayeyarwady River suggest that electrofishing and associated activities by gangs of fishermen in motorized vessels have disrupted the traditional mutualistic fishing relationship between humans and Irrawaddy dolphins (Smith et al. 2009). In this relationship, the dolphins, upon receiving an acoustic signal from net-fishermen in non-motorized boats, approached the boats and assisted the fishing operation by herding fish toward the nets (Smith \& Tun 2007). Already by the mid-2000s, the dolphins reportedly had begun to stay away from certain areas to avoid being shocked (Smith \& Tun 2007), and more recent observations (in 2012 and 2014) indicate that they rarely approach oar-powered boats to engage in 'cooperative' fishing (Holland 2015, https://www.marinemammalscience.org/letters/letter-to-myanmar-officials-regarding-irrawaddy-dolphins/).

Anecdotal evidence suggests that electro-fishermen have taken advantage of the normal fish-herding behavior of dolphins in the Ayeyarwady by signaling to the dolphins using acoustic means, similar to the cooperative cast-net fishermen (see Smith et al. 2009), so that they can deploy their electrical gear near the dolphins to catch more fish (A. M. Chit pers. comm.). Exploiting what used to function as mutually beneficial interspecies signaling, the electro-fishermen might switch off the electrical current as dolphins move into an area (generally an indication of fish presence) and then turn it back on to stun the fish that try to escape ahead of the approaching dolphins. This situation could put dolphins in close proximity to electrodes as the electrical current is activated, a situation that could lead to injury or even death of the dolphins (Myanmar Times 6-12 August 2012 https:// www.mmtimes.com/national-news/mandalay-uppermyanmar/239-battery-fishing-rise-threatens-uniquedolphin-cooperation.html).

In some circumstances, Mahakam river dolphins appear to co-exist with electrofishing operations and approach the boats and gear without apparent harm. On several occasions, one of the authors (D. Kreb) observed dolphins as close as $15 \mathrm{~m}$ to a boat that was actively electrofishing. The dolphins showed no obvious reaction but appeared to be eating fish that had been stunned or escaped from the electrical field.

\subsubsection{Pathology and diagnosis of electrofishing as cause of death of freshwater cetaceans}

It is widely assumed, implied, or asserted in the literature that exposure to electrofishing can electrocute or stun freshwater cetaceans. In the river-by-river review below, we consider scientific and popular accounts that cite electrofishing as a possible or known cause of death of cetaceans. 
Table continued on next page

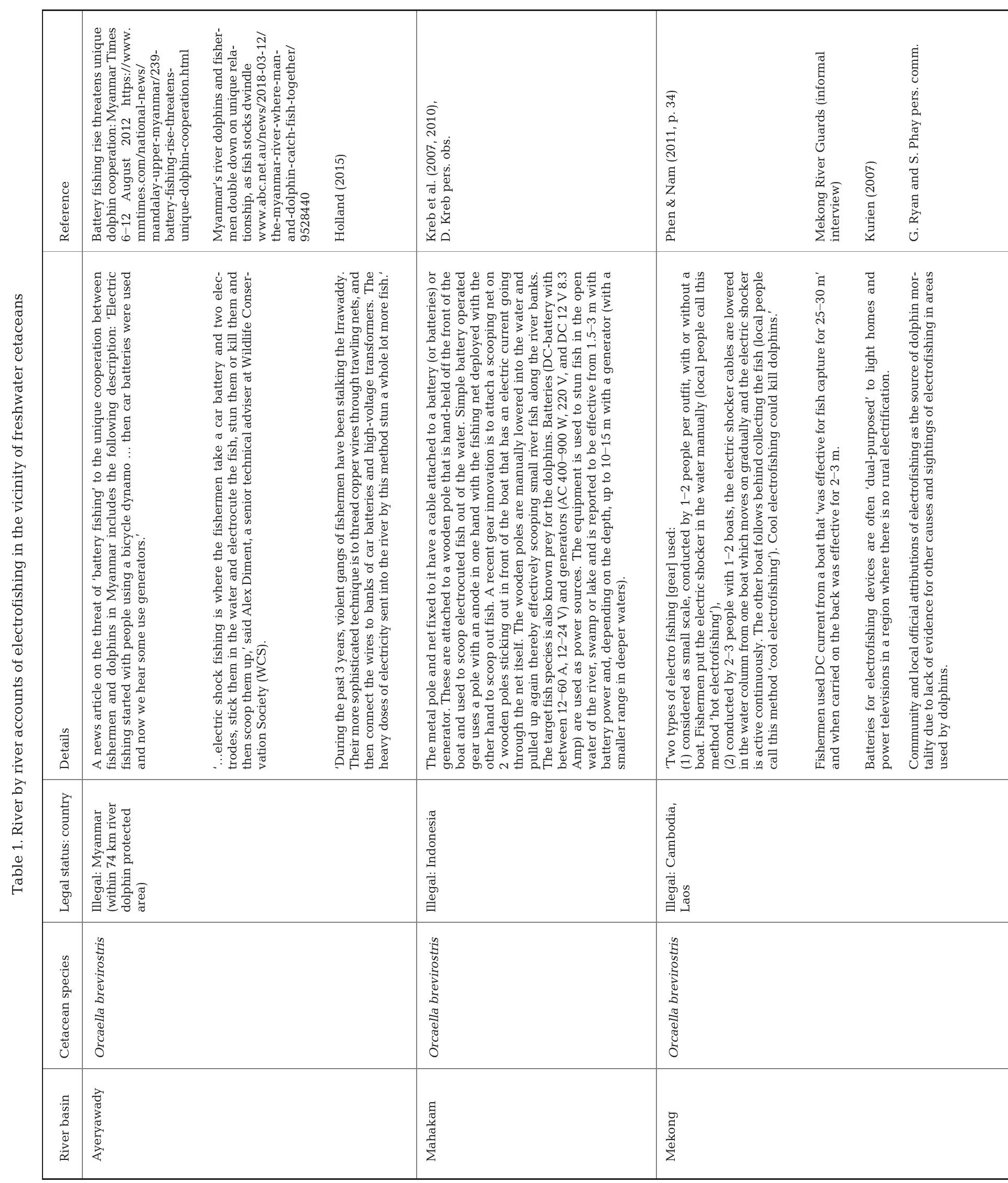




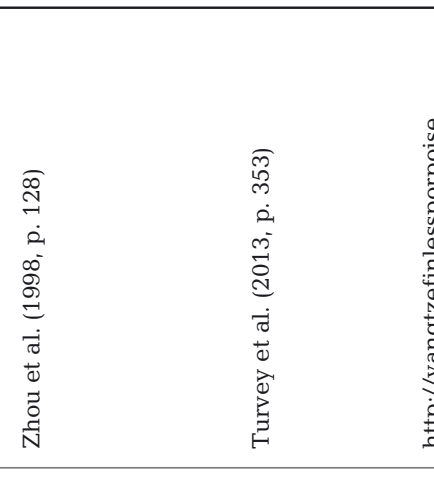

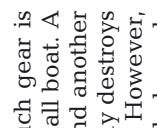

nin

min

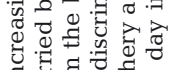

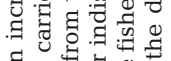

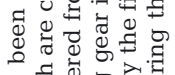

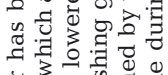

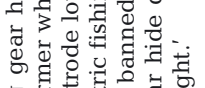

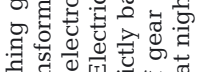

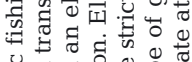

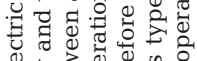

ब.

岁

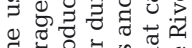

\$

蛋

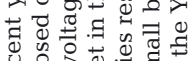

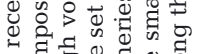

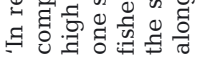

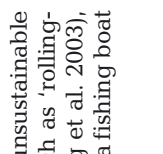

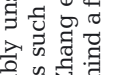

중 융 경

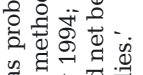

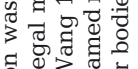

율

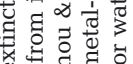

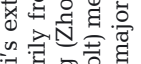

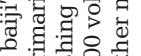

물

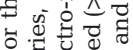

跑

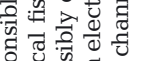

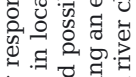

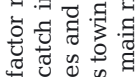

记

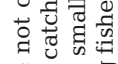

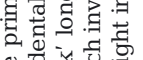

IIn

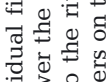

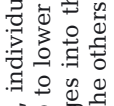

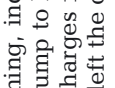

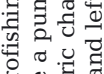

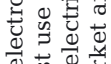

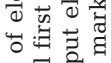

苨运

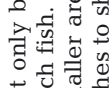

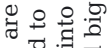

Wh

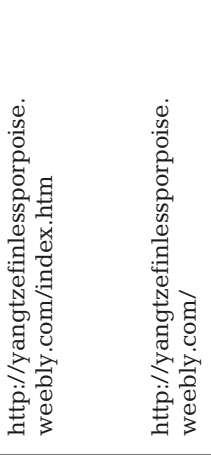

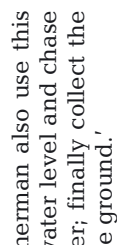

可

n月.

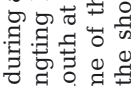

ठ
词焉

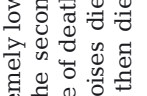

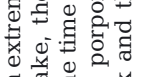

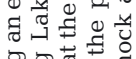

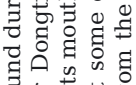

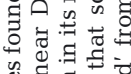

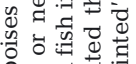

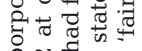

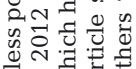

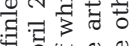

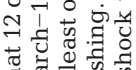

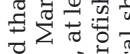

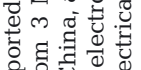

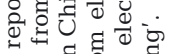

웜

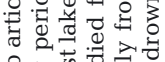

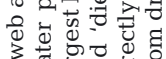

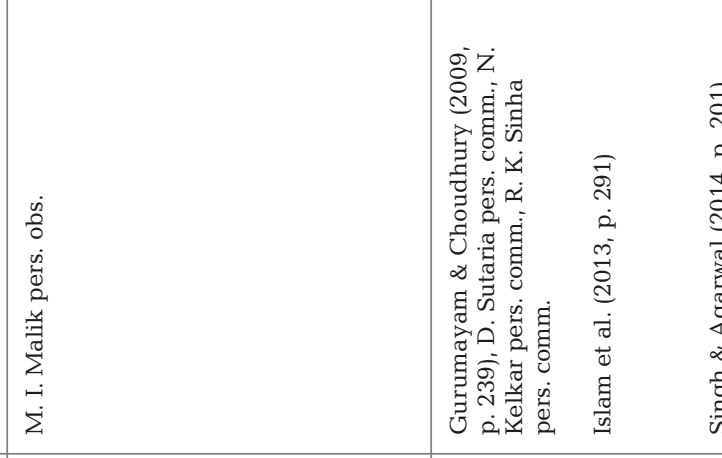

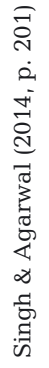

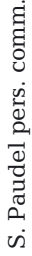

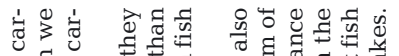

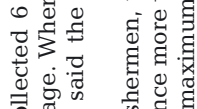

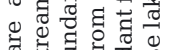

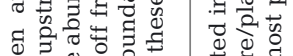

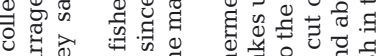

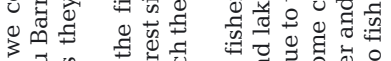

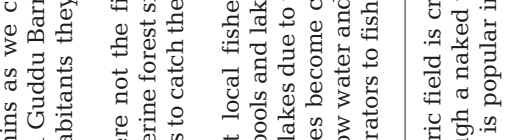

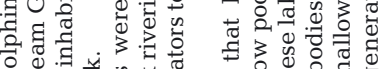

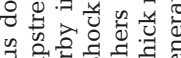

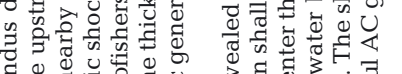

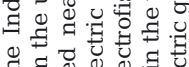

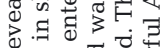

w w w

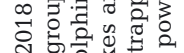

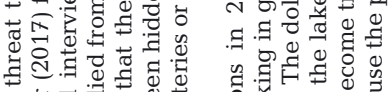

政

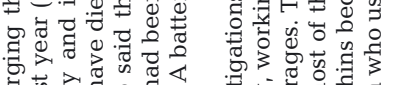

等

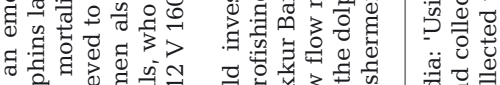

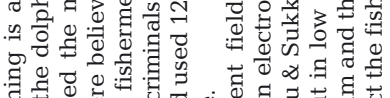

: ${ }^{\infty}$.

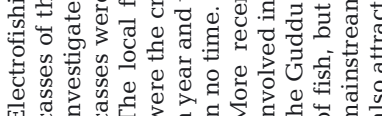

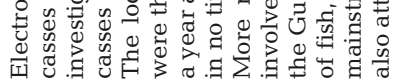

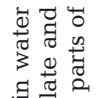

究:

구요

品

过

एँ

प 등.

흥

व 8 व

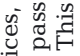

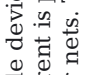

界

记 类

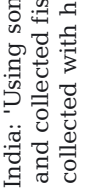

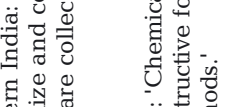

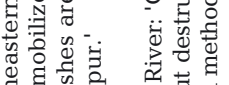

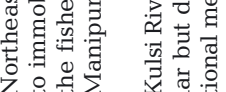

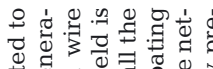

跣

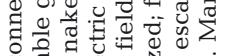

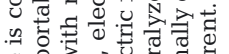

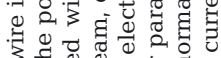

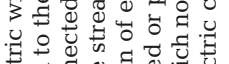

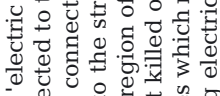

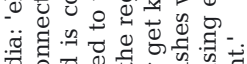

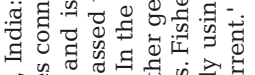

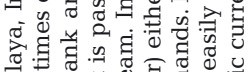

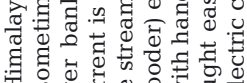

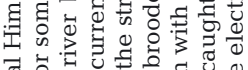
西嵒记 ज्ञ

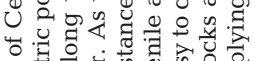

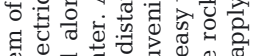

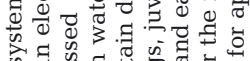

की

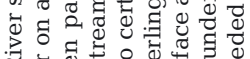

舫过

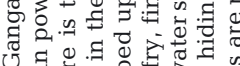

U.

过

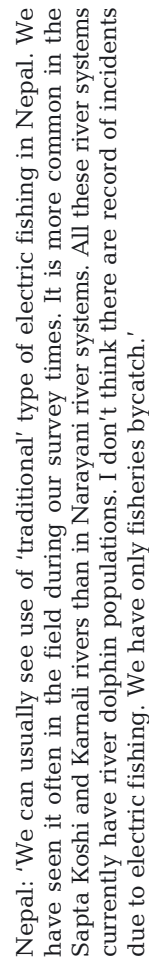

递

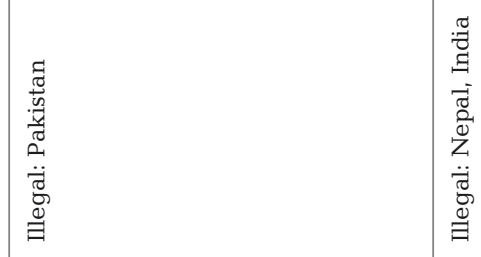

苛

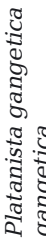

్ㅗㅁ

$\frac{2}{9}$

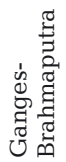


As with most cetacean deaths other than those caused by deliberate hunting or fishery bycatch (at least when the animal is found in the gear), the cause of death of freshwater cetaceans usually has to be determined from examining tissues obtained from carcasses. Death by electricity is often invoked as the cause when carcasses are unmarked or bear little external or internal evidence of fishery interaction, disease, or trauma (Zhou et al. 1998). Cause of death has been attributed to electrofishing for Yangtze finless porpoises, baijis, Indus River dolphins (bhulans), and Irrawaddy dolphins in the Mahakam, Mekong, and Ayeyarwady rivers (Table 1).

Conclusively identifying electric shock as a cause of death is difficult, and the absence of signs caused by other factors such as net entanglements or propeller wounds does not necessarily imply electric shock as the cause of death. In humans, electrocution is identified by histological detection of damage to cardiac muscle and, in cases of severe electric shock (e.g. lightning strike), burning of surface tissue (Wright \& Davis 1980, Fineschi et al. 2006). Ideally, a sample of fresh cardiac muscle tissue is available that can be fixed in formalin and examined histologically to detect characteristic lesions of cardiomyopathy. However, it is rare to recover carcasses of freshwater cetaceans, and even more rare for someone to recover samples within $24 \mathrm{~h}$ of death and fix them in formalin for histological examination.

\subsection{River-by-river reports}

Table 1 provides the details of reports of electrofishing and operational interactions with freshwater cetaceans in the rivers of Asia.

\subsubsection{Yangtze River}

Yangtze River finless porpoises. Reports of electrofishing as the possible cause of death of cetaceans come most frequently from China and involve Yangtze finless porpoises and baijis in the Yangtze River. The most commonly reported sources of mortality of finless porpoises in the Yangtze are boat strikes and entanglement in fishing gear.

The most recent reports of finless porpoise mortality from electrofishing and other illegal fishing activities come from the 2 large lakes (Poyang and Dongting lakes) adjoining the Yangtze River (Fig. 1). Mei et. al. (2019) reported that of the 29 out of 60 dead porpoises collected from 2008 to 2013 from Poyang
Lake (the largest lake in China) for which cause of death could be determined, 11 (37.9\%) were killed directly by illegal fishing (1 by rolling hooks, 3 by set nets, and 7 by electrofishing gear) and only 1 was killed by a propeller strike. In 2009 during a low-water period at Poyang Lake, several porpoises were found that had been injured or killed by entanglement in fixed stake nets (http://english.ihb. cas.cn/rh/rp/201003/t20100319_51725.html).

The cause of death was determined for 7 out of 22 dead porpoises collected from 2008 to 2012 in Dongting Lake: 4 were killed by illegal fishing ( 2 by electrofishing, 1 by rolling hooks, and 1 by set nets) and 3 were killed by propeller strikes. In addition to risks posed by illegal fishing gear and methods, the finless porpoises in the lakes adjoining the Yangtze River are exposed to other threats, including toxic pollution and disturbance from sand mining and dredging activities (Wang \& Reeves 2017). There was concern that the increasing use of both stake nets and electrofishing during times of low water would increase the risk of injury to the porpoises.

In a personal communication to F. M. D. Gulland (10 July 2017), Dr. Zheng Jinsong of the Institute of Hydrobiology, Chinese Academy of Sciences, noted that electrofishing was inferred to be the cause of death for Yangtze finless porpoises by ruling out other possible causes, such as boat impact or propeller wounds, entanglement in fishing gear, disease, or starvation, and on the basis of the presence of electrofishing in the area. Usually, the carcasses for which electrocution was assigned as the cause of death were intact without any obvious trauma or wounds, although sometimes there were lesions such as blood spots in the blubber, signs of 'sclerosis' of the heart (distended blood vessels), symptoms of asphyxiation in the lungs, and intact prey fish in the forestomach, all supportive of a diagnosis of sudden death due to electrocution. For example, investigators concluded that an adult female finless porpoise that stranded with no obvious evidence of external or internal trauma, appeared to be in good health, and had fed just prior to death, was most likely killed by electrofishing (Turvey 2009, https://www.edgeof existence.org/blog/what-is-killing-finless-porpoisesin-the-yangtze/).

Baijis. Electrofishing has been widely cited as a contributing factor in the decline and extinction of the baiji (Chen \& Liu 1992, Turvey et al. 2007, Smith et al. 2017), although mortality caused by rolling hook longlines, gillnets, fish traps, boat propellers, and explosives was more conclusively documented (Perrin \& Brownell 1989, Zhou \& Zhang 1991). Death 


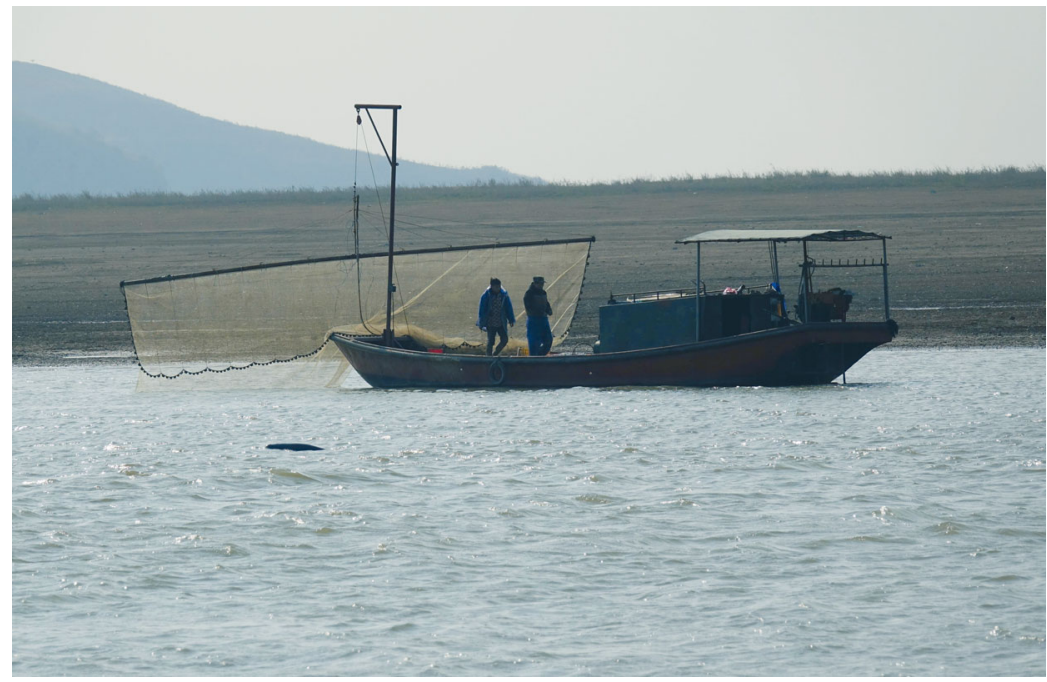

Fig. 1. Yangtze River finless porpoise (foreground) near large electrofishing boat with an electrified trawl in Poyang Lake, China, December 2017. Electric current from the wires on the net stuns or kills fish, which are then collected by the net. Despite the presence of electrofishing, entanglement in fishing gearremains the greatest threat to freshwater cetaceans. Photo credit: Dr. X. Yijie

concluded that these last 4 were 'possibly killed by shocks of electric fishing,' which reportedly was increasing on the river at the time. In a sample of 12 baiji carcasses examined between 1990 and 1999 (apparently distinct from those reported by Zhou et al. 1998), a cause of death was given for 10 , of which 4 were said to have died from electrocution (Zhang et al. 2003). This appears to be the source of the conclusion that electrofishing accounted for $40 \%$ of baiji deaths in the 1990s and was 'apparently the biggest threat to baiji survival' (Turvey 2008, p. 39). While the possibility of deaths from electrofishing cannot be discounted, little or no direct evidence was provided to substantiate these cause-of-death determinations (Wang et al. 2006, Smith et al. 2017).

The reports on the 2 species (baiji and finless porpoise) from the Yangtze

from electrofishing was usually inferred from a lack of external marks or internal injuries on carcasses when animals were found dead with no observed lesions, electrofishing was often judged to be the most probable cause of death. The most direct statement related to the baiji comes from the 1980s, when Chen \& Hua (1989, p. 84) stated, 'In some cases, the electrofishing teams are formed by several electrofishing vessels cooperating with small boats. One dolphin was killed in February 1981 near Paizhou in this way.'

The limited information on causes of baiji deaths, summarized below, suggests that the overall contribution of electrofishing to the species' demise is less certain than is sometimes implied or stated in the literature.

In the middle reaches of the Yangtze, 15 of 28 recorded baiji deaths from 1973 to 1983 were caused by rolling hook longlines (Zhou \& Wang 1994). Of 31 baiji carcasses from the lower Yangtze examined to determine cause of death between 1978 and 1985, 13 were entangled in rolling hook longlines or caught in nets, 6 were killed by illegal fishing with explosives, 10 were struck by propellers, 1 was trapped in a sluice gate, and 1 was simply reported as stranded (Zhou \& Li 1989). Of 13 carcasses from the lower Yangtze examined between 1989 and 1996, 3 were found entangled with hooks, 1 bore propeller wounds, and 4 had no evidence of entanglement in nets or rolling hook longlines (Zhou et al. 1998, p. 128). In the absence of an obvious cause, Zhou et al. (1998)
River suggest 2 possible scenarios in which electrocution of cetaceans could occur: (1) the animals are entrapped by declining water levels in segments of a lake or side-channel of the river, and (2) the dolphins or porpoises are corralled, intentionally or unintentionally, by multiple electrofishing boats working together. The entrapped or encircled animals might then be exposed to electric shock at close proximity as the fishermen seek to stun the fish near them (Lin et al. 1985, Chen \& Hua 1989, Zhou \& Li 1989, Zhou \& Wang 1994, Zhou et al. 1998, Zhang et al. 2003).

\subsubsection{Indus River dolphins}

Electrofishing is regarded as an emerging threat in Pakistan. Six dolphin carcasses (4 males, 2 females) were collected between 10 October and 12 December 2017 from an area 5-10 km upstream of the Guddu Barrage (M. I. Malik unpubl. data). Nearby villagers who were interviewed said they believed that the animals had died from electric shock in the vicinity of electrofishing conducted by criminals operating out of the thick riparian forest. More recent field investigations in 2018 revealed that local fishermen are also involved in electrofishing, working in groups in shallow pools and lakes upstream of the Guddu and Sukkur barrages where they might encounter dolphins (M. I. Malik unpubl. data). 


\subsubsection{Ganges River dolphins}

Electrofishing is practiced in various forms in the Ganges River (see Table 1) but we have found no reports of Ganges River dolphins being affected.

\subsubsection{Irrawaddy dolphins in the Mahakam River}

Fishermen in the Mahakam River reported 2 deaths of Irrawaddy dolphins suspected to have resulted from electric shock, one in 2003 (Kreb et al. 2007) and one in 2008 (Kreb et al. 2010). On the first occasion, a dead juvenile dolphin was seen floating with a blue bruise on its head after it came in contact with an electrofishing boat. On the second occasion, some people were observed fishing with high-voltage AC generators in small pools and channels of the upstream section of the Mahakam. They were deliberately chasing and harassing dolphins, and not long afterward, a fisherman observed a dead calf floating downstream. According to his statement, the dead calf's belly was blue.

In the first instance, the dolphin apparently came in direct contact with the electrodes of the electrofishing apparatus and was electrocuted. The second of these reports suggests that in the small pools and channels of the upper Mahakam it is more difficult for dolphins to avoid the fishing activity than it is in broader downstream reaches. D. Kreb has also observed dolphins approaching and then moving away from electrofishing operations without harm, indicating that proximity alone does not necessarily lead to death or injury (Fig. 2).

\subsubsection{Irrawaddy dolphins in the Ayeyarwady River}

Electrofishing has been mentioned repeatedly as a cause of dolphin mortality in the Ayeyarwady River, and some recent observations were mentioned above. Smith \& Tun (2007) cited electrocution as a direct threat, but provided few details. On 4 December 2014, 2 dead young dolphins (male and female) were found on the same day in a protected stretch of the river north of Mandalay with no sign of entanglement and 'no sign of toxics.' According to a journalist (Holland 2015), sources he interviewed stated that necropsies showed the dolphins to have been victims of electrofishing. This report, like so many that cite electrocution as the cause of death of freshwater cetaceans, has proven impossible to validate.

\subsubsection{Irrawaddy dolphins in the Mekong River}

Electrofishing has been reported and considered as a possible cause of death for Irrawaddy dolphins in the Mekong River. It is reported as a widespread and common practice within and around dolphin habitat (Phen \& Nam 2011) and has been the subject of significant enforcement efforts. From October 2013 to May 2017, river guards aggressively enforced the ban on electrofishing, with 53 cases of interdiction and confiscation of electroshock units (including inverters, batteries, and wires) (S. Keo pers. comm.). This enforcement effort was centered on what are called core dolphin areas and buffer zones. The river guards encountered electrofishing during day and night, but mostly at night. Electro-fishermen were said to fish from motorboats in mid-stream, not along the shore.

Carcass recovery and investigations of the causes of dolphin mortality have been carried out in the Mekong in southern Laos and Cambodia since the early to mid 1990s (Baird \& Mounsouphom 1994, 1997, Gilbert \& Beasley 2005, WWF \& FiA 2014, 2017). The presence of external net marks with no internal lesions and full stomachs is almost always interpreted to indicate gillnet entanglement as the cause of death. Although electrofishing has never been demonstrated as having a role in the death of dolphins in the Mekong River, the appearance of unmarked carcasses (often neonates or very young calves) that lack evidence of net entanglement or other wounding has led to speculation that electrofishing is a source of mortality (G. Ryan and S. Phay pers. obs.). Since 2012 there has been an effort (led by WWF-Cambodia) to secure and perform necropsies on the carcasses of these young dolphins. Roughly $20 \%$ exhibit internal evidence of blunt trauma that, while still poorly documented, may be the result of intraspecific interactions in which adult dolphins rush at and hit calves, sometimes throwing them out of the water; at least some of these interactions occur at or near the time of birth (WWF \& FiA 2017). Until other possible causes such as infectious diseases and toxicosis have not been ruled out, death from electrofishing interaction is not indicated for these young animals.

\section{CONCLUSIONS}

While we do not have any information on the electrical power required to injure or kill a dolphin or porpoise, or how closely an animal would have to approach an electrical field to be injured or killed, 


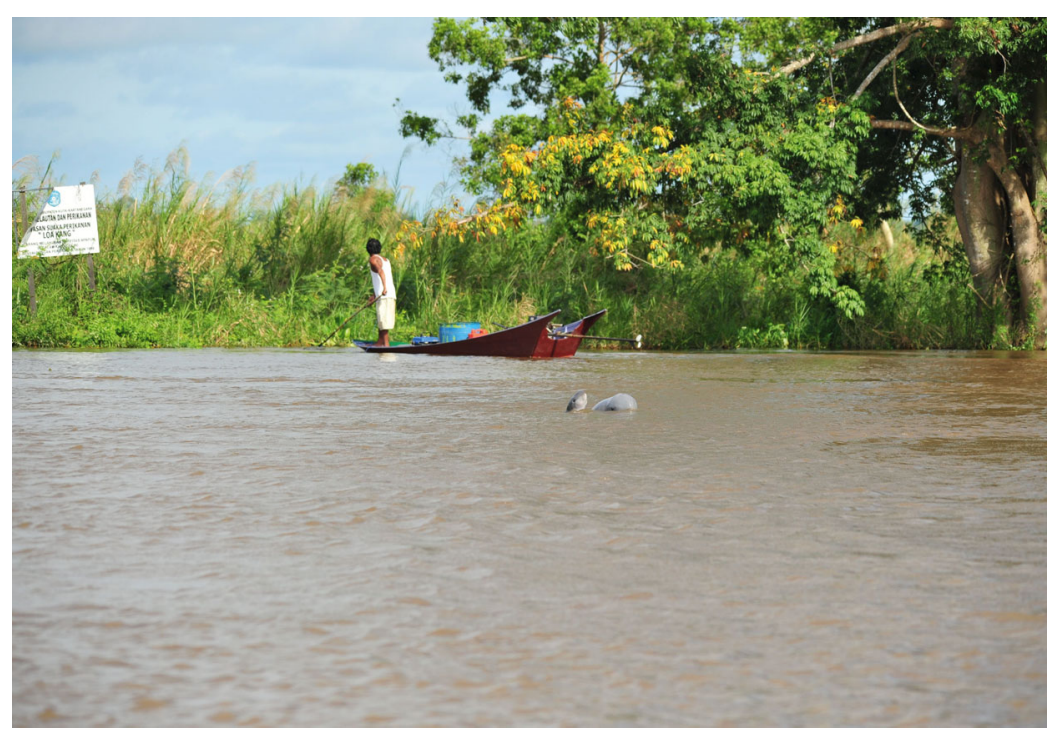

Fig. 2. Small boat fishing with electrofishing gear powered by a portable electric generator in the vicinity of an Irrawaddy dolphin mother and calf pair, Mahakam River, Indonesia. Areas of abundant fish such as deep pools, confluences, and eddies may draw freshwater cetaceans and fishermen into close proximity. Photo credit: D. Kreb, Yayasan Rasi

the general factors of increasing impact of electricity on organisms of larger body size, mammalian susceptibility to respiratory and cardiac impacts from electrical currents, and decreased electrical resistance of the hairless, poorly keratinized cetacean skin in water, all suggest that freshwater cetaceans are at risk of injury or death if they come in close enough contact with electrical fields. The reporting of illegal electrofishing, confiscation of gear, and anecdotal reports of carcasses with no external evidence of trauma from nets or lines or vessel strike all support the concern that electrofishing poses a threat to endangered cetacean populations.

Unlike electric whaling, electrofishing techniques are usually designed to stun fish as they encounter electrical fields, not to electrocute the fish by direct contact with electrodes. We have found no evidence of intentional electrocution of dolphins or porpoises by fishermen in the rivers of Asia and are unaware of any incentive for such a practice to evolve (but see Robards \& Reeves [2011] for discussion of how the consumption of marine mammals, and in turn their deliberate capture, has arisen out of other types of bycatch mortality).

Whether, and under what conditions, free-swimming dolphins or porpoises would move into the vicinity of electrofishing operations that could harm or kill them and how close they would have to come to be harmed remain open questions. The evidence cited above, that cetaceans can detect low-level elec- trical fields and that pinnipeds and other aquatic mammals are deterred by them, suggests that free-swimming freshwater cetaceans could detect and avoid such fields as long as they recognize the danger. This capability of detection and avoidance would depend on how the electrofishing equipment is deployed in the vicinity of cetaceans: whether the electric current is on continuously, turned on and off to conserve energy, or deployed in a manner to optimize the number of fish killed or stunned. It also may depend on the earlier experiences of the cetaceans swimming close to electrical fields - a novel experience could arouse curiosity, particularly in young animals, inducing them to swim closer to investigate. The few observations that we have to go on suggest the following scenarios where cetaceans might be put at risk: (1) entrapment in shallow water or restricted river or lake areas (resulting from drought, or the intentional draining or enclosure of water bodies to entrap fish) and subsequent inability to move away from electrofishing activities (e.g. Yangtze finless porpoises); (2) encounters between cetaceans and electrofishing activities in naturally restricted river reaches such as shallow upstream areas and narrow tributaries where it is difficult to move away from the electrical charges in the water (e.g. Mahakam and Indus dolphins); (3) incidental or deliberate corralling of cetaceans into the proximity of electrofishing apparatus by multiple fishing boats working together (e.g. baijis and Ayeyarwady and Mahakham dolphins); (4) appropriation by electrofishermen of the mutualistic behavioral cues used by dolphins and throw-net fishermen ('coopera tive fishing') to get near fish concentrations (e.g. Ayeyarwady dolphins); (5) intentionally leaving electrofishing gear switched off and allowing cetaceans to approach an area while chasing fish, then turning the current back on when the cetaceans are inside the 'effective' danger zone to stun the fish herded in by the dolphins (e.g. Ayeyarwady dolphins); and (6) attraction of cetaceans to fish that have been immobilized by electrofishing activities (e.g. Mahakam dolphins).

Except possibly in the case of Ayeyarwady thrownet fishermen exploiting the mutualistic relationship between them and dolphins, and the single reported case of harassment in the Mahakam, we found no 
evidence of people intentionally drawing cetaceans into the proximity of electrofishing operations in order to capture, kill, or harass them.

Mortality of cetaceans from exposure to electrofishing appears to be uncommon, but this must be considered in the context of populations with fewer than 100 individuals in several river systems (Irrawaddy dolphins in the Mahakam, Mekong, and Ayeyarwady rivers) or that are surrounded by human activity and subject to numerous threats (finless porpoises in the Yangtze River). Diagnosis of cause of death for stranded cetaceans is generally difficult, but particularly so for determining death by electrocution (or electrically induced paralysis and subsequent drowning). Fresh carcasses suitable for histological examination of tissues, and collection and formalin fixation of heart and lung tissue are needed, but in most circumstances, there is little or no local expertise in field necropsy techniques.

This review indicates a need for further assessment of electrofishing practices and of when and how such fishing might threaten freshwater cetaceans. Knowing more about the nature of interactions between the animals and the operations, the ability of cetaceans to detect and respond to electrical currents, the impact on immersed mammals of the electrical fields produced by electrofishing, and diagnostic histology on tissues from dead animals would enable improved assessment of the implications for conservation. We acknowledge, however, that pursuing research on the effects of electrical currents on cetaceans and their ability to detect currents is ethically and logistically challenging, and thus not a recommended avenue to pursue. Rather, efforts should focus on obtaining fresh carcasses to determine cause of death through histological examination of fresh tissues fixed in formalin, as this will also enhance detection of other threats.

Acknowledgements. The authors thank Jan Dean and Alan Temple, who teach legal electrofishing sampling techniques at the US Fish and Wildlife Service, for sharing their expertise. We thank Ravindra K. Sinha, Dipani Sutaria, and Natchiket Kelkar for information from India and Shambhu Paudel for information from Nepal. F. M.D.G. thanks the Marine Mammal Center where she was employed during the development of this paper. R.R.R. thanks the Marine Mammal Commission for covering part of his time while working on this paper.

\section{LITERATURE CITED}

Baird IG, Mounsouphom B (1994) Irrawaddy dolphins (Orcaella brevirostris) in southern Lao PDR \& northeastern Cambodia. Nat Hist Bull Siam Soc 42:159-175

Baird IG, Mounsouphom B (1997) Distribution, mortality, diet and conservation of Irrawaddy dolphins (Orcaella brevirostris Gray) in Lao PDR. Asian Mar Biol 14:41-48

* Bohlin T, Hamrin S, Heggberget TG, Rasmussen G, Saltveit SJ (1989) Electrofishing - theory and practice with special emphasis on salmonids. Hydrobiologia 173:9-43

*Baulik GT, Smith BD (2017) Platanista gangetica. The IUCN Red List of Threatened Species 2017:e.T41758A50383612. https://www.iucnredlist.org/species/41758/50383612 (accessed 2 July 2019)

* Braulik, GT, Smith BD, Sinha R (2012) Platanista gangetica ssp. gangetica. The IUCN Red List of Threatened Species 2012:e.T41757A17628296. http://dx.doi.org/10.2305/ IUCN.UK.2012.RLTS.T41757A17628296.en (accessed 16 August 2018)

* Burger C (2008) Behavioral deterrence responses of captive California sea lions exposed to a mild, electric voltage gradient at Moss Landing Marine Labs, CA. Report submitted to Bonneville Power Administration as part of Project 2007-524-00, Contract 43248. https://www.mediate.com/ DSConsulting/docs/Smoth-Root\%202010\%20Report.pdf (accessed 12 January 2019)

Chen P, Hua Y (1989) Distribution, population size and protection of Lipotes vexillifer. In: Perrin W, Brownell R, Zhou $\mathrm{K}$, Liu J (eds) Biology and conservation of the river dolphins. Occasional Papers, IUCN Species Survival Commission 3. World Conservation Union, Gland, p 81-85

Chen P, Liu R (1992) Baiji: a rare treasure. Institute of Hydrobiology, Wuhan (in Chinese and English, with notes by T. Kasuya)

Czech-Damal NU, Liebschner A, Miersch L, Klauer G and others (2012) Electroreception in the Guiana dolphin (Sotalia guianensis). Proc R Soc B 279:663-668

da Silva VMF, Trujillo F, Martin A, Zerbini AN and others (2018a) Inia geoffrensis. The IUCN Red List of Threatened Species 2018:e.T10831A50358152. http://dx.doi.org/10. 2305/IUCN.UK.2018-2.RLTS.T10831A50358152.en

da Silva VMF, Freitas CEC, Dias RL, Martin AR (2018b) Both cetaceans in the Brazilian Amazon show sustained, profound population declines over two decades. PLOS ONE 13:e0191304

* Dalbey SR, McMahon TE, Fredenberg W (1996) Effect of electrofishing pulse shape and electrofishing-induced spinal injury on long-term growth and survival of wild rainbow trout. N Am J Fish Manage 16:560-569

Di Nunno N, Vimercati L, Viola L, Vimercati F (2003) A case of electrocution during illegal fishing activities. Am J Forensic Med Pathol 24:164-167

Dolan CR, Miranda LE (2003) Immobilization thresholds of electrofishing relative to fish size. Trans Am Fish Soc 132: 969-976

Emery L (1984) The physiological effects of electrofishing. Cal-NEA Wildlife Transactions, p 59-72

FAO (2016) The state of world fisheries and aquaculture 2016. Contributing to food security and nutrition for all. FAO, Rome

Fineschi V, Karch SB, D'Errico S, Pomara C, Riezzo I, Turillazzi E (2006) Cardiac pathology in death from electrocution. Int J Legal Med 120:79-82

Forrest KW, Cave JD, Michielsens CGJ, Haulena M, Smith DV (2009) Evaluation of an electric gradient to deter seal predation on salmon caught in gill-net test fisheries. N Am J Fish Manage 29:885-894

Garcia SM, Zerbi A, Aliaume C, Do Chi T, Lasserre G (2003) The ecosystem approach to fisheries. FAO Fish Tech Pap 443:1-71 
Gilbert M, Beasley I (2005) Mekong River Irrawaddy dolphin stranding and mortality summary, January 2001-December 2005. Wildlife Conservation Society Tech Rep, Phnom Penh

Green EK (2011) Telephoning fish: an examination of the creative deviance used by wildlife violators in the United States. Int J Rural Criminol 1:23-39

Gurumayam SD, Choudhury M (2009) Fishing methods in the rivers of Northeast India. Indian J Trad Knowl 8:237-241

Harrison RJ, Thurley KW (1974) Structure of the epidermis in Tursiops, Delphinus, Orcinus and Phocoena. In: Harrison RJ (ed) Functional anatomy of marine mammals, Vol 2. Academic Press, London, p 45-73

Holland H (2015) Rogue 'electro-fishing' puts river dolphins at risk in Myanmar. http://news.nationalgeographic.com/ news/2015/02/150217-irrawaddy-dolphins-myanmarelectro-fishing-mandalay (accessed 16 August 2018)

Islam MR, Das B, Baruah D, Biswas SP, Gupta A (2013) Fish diversity and fishing gears used in the Kulsi River of Assam, India. Ann Biol Res 4:289-293

Jefferson TA, Karczmarski L, Kreb D, Laidre K and others (2008) Orcaella brevirostris (Mahakam River subpopulation). The IUCN Red List of Threatened Species 2008: e.T39428A98842174. http://dx.doi.org/10.2305/IUCN.UK. 2008.RLTS.T39428A10237530.en (accessed 16 August 2018)

Kolz AL (1989) Electrofishing, a power related phenomenon. U.S. Department of Interior, Fish and Wildlife Service, Fish and Wildlife Tech Rep 22

Kolz AL, Johnson RE (1995) In-water electroshock techniques to repel aquatic mammals and birds. In: Mason JR (ed) Repellents in wildlife management symposium proceedings. National Wildlife Research Center Repellents Conference, 8-10 August 1995, Denver, CO. National Wildlife Research Center, Fort Collins, CO, p 203-215. http://digitalcommons.unl.edu/cgi/viewcontent.cgi?article $=1022 \&$ context $=$ nwrcrepellants

Kreb D, Budiono, Syachraini (2007) Review of status and conservation of Irrawaddy dolphins Orcaella brevirostris in the Mahakam River of East Kalimantan, Indonesia. In: Smith BD, Shore RG, Lopez A (eds) Status and conservation of freshwater populations of Irrawaddy dolphins. Working Paper No. 31. Wildlife Conservation Society, New York, NY, p 53-66

Kreb D, Reeves RR, Thomas PO, Braulik G, Smith BD (eds) (2010) Establishing protected areas for Asian freshwater cetaceans as flagship species for integrated river conservation management, 19-24 October 2009, Samarinda. Final workshop report. www.mmc.gov/wp-content/ uploads/asian_fw_dolphin_ws.pdf (accessed 2 July 2019)

Kurien J (2007) Shocking reality: Cambodia electrofishing. SAMUDRA Rep 48:35-36

Lin KJ, Chen PX, Hua YY (1985) Population size and conservation of Lipotes vexillifer. Acta Ecol Sin 5:77-85 (in Chinese with English summary)

Mahoney BD, Iverson TK, Mathews SB (1993) Synopsis and annotated bibliography on electrofishing with special reference to Columbia River squawfish control. Fisheries Research Institute, Seattle, WA

Mei Z, Han Y, Dong L, Turvey ST and others (2019) The impact of fisheries management practices on the survival of the Yangtze finless porpoise in China. Aquat Conserv 29:639-646

Minton G, Smith BD, Braulik GT, Kreb D and others (2017) Orcaella brevirostris (errata version published in 2018).
The IUCN Red List of Threatened Species 2017: e.T15419A123790805. http://dx.doi.org/10.2305/IUCN. UK.2017-3.RLTS.T15419A50367860.en (accessed 16 August 2018)

Mitchell E (1986) Aspects of pre-World War II German electrical whaling. Rep Int Whal Comm Spec Issue 7: 115-139

Perrin WF, Brownell, RL Jr (eds) (1989) Report of the workshop. In: Perrin WF, Brownell RL Jr, Zhou K, Lin J (eds) Biology and conservation of the river dolphins. Occasional Papers of the IUCN Species Survival Commission No. 3, p 1-22

* Phen C, Nam S (2011) Assessment of gillnets and other fishing gear used in the Mekong River between Kratie and the Lao PDR border. Inland Fisheries Research and Development Institute (IFReDI) Fisheries Administration. http://ifredi-cambodia.org/wp-content/uploads/2014/08/ Chheng_Phen__So_Nam_2011_Assessment-of-gillnetsand-other-fishing-gears.pdf

Primavesi R (2009) A shocking episode. Can Fam Physician 55:707-709

Reynolds J, Harlan L (2011) Quick-start guide to electrofishing. Smith-Root, Vancouver, WA

Reynolds J, Kolz AL (2013) Electrofishing. In: Zale AV, Parrish DL, Sutton TM (eds) Fisheries techniques, $3^{\text {rd }}$ edn. American Fisheries Society, Bethesda, MD, p 305-361

Robards MD, Reeves RR (2011) The global extent and character of marine mammal consumption by humans: 1970-2009. Biol Conserv 144:2770-2786

Secchi E (2012) Sotalia fluviatilis. The IUCN Red List of Threatened Species 2012: e.T190871A17583369. https:// www.iucnredlist.org/species/190871/17583369 (accessed 2 July 2019)

* Singh G, Agarwal NK (2014) Fishing methods in upper Ganga River system of Central Himalaya, India. J Fish 2:195-202

* Smith BD (2004) Orcaella brevirostris (Ayeyarwady River subpopulation). The IUCN Red List of Threatened Species 2004: e.T44556A10919593. http://dx.doi.org/10.2305/ IUCN.UK.2004.RLTS.T44556A10919593.en (accessed 16 August 2018)

* Smith BD, Beasley I (2004) Orcaella brevirostris (Mekong River subpopulation). The IUCN Red List of Threatened Species 2004:e.T44555A10919444. http://dx.doi.org/10. 2305/IUCN.UK.2004.RLTS.T44555A10919444.en (accessed 10 November 2018)

Smith BD, Tun MT (2007) Review of the status and conservation of Irrawaddy dolphins Orcaella brevirostris in the Ayeyarwady River of Myanmar. In: Smith BD, Shore RG, Lopez A (eds) Status and conservation of freshwater populations of Irrawaddy dolphins. Working Paper No. 31. Wildlife Conservation Society, New York, NY, p 21-39

Smith BD, Tun MT, Chit AM, Win H, Moe T (2009) Catch composition and conservation management of a human-dolphin cooperative cast-net fishery in the Ayeyarwady River, Myanmar. Biol Conserv 142:1042-1049

Smith BD, Braulik GT, Sinha R (2012) Platanista gangetica ssp. gangetica. The IUCN Red List of Threatened Species 2012: e.T41756A17627639. https://www.iucnredlist.org/species/ 41756/17627639 (accessed 2 July 2019)

Smith BD, Wang D, Braulik GT, Reeves R and others (2017) Lipotes vexillifer. The IUCN Red List of Threatened Species 2017:e.T12119A50362206. http://dx.doi.org/10. 2305/IUCN.UK.2017-3.RLTS.T12119A50362206.en (accessed 29 March 2019) 
Snyder DE (2003) Invited overview: conclusions from a review of electrofishing and its harmful effects on fish. Rev Fish Biol Fish 13:445-453

Turvey ST (2008) Witness to extinction: how we failed to save the Yangtze River dolphin. Oxford University Press, Oxford

Turvey ST, Pitman RL, Taylor BL, Barlow J and others (2007) First human-caused extinction of a cetacean species? Biol Lett 3:537-540

* Turvey ST, Risley CT, Moore JE, Barrett LA and others (2013) Can local ecological knowledge be used to assess status and extinction drivers in a threatened freshwater cetacean? Biol Conserv 157:352-360

Wang JY, Reeves R (2017) Neophocaena asiaeorientalis. The IUCN Red List of Threatened Species 2017: e.T41754A50381766. http://dx.doi.org/10.2305/IUCN.UK. 2017-3.RLTS.T41754A50381766.en (accessed 8 January 2019)

Wang K, Wang D, Zhang X, Pfluger A, Barrett L (2006) Rangewide Yangtze freshwater dolphin expedition: The last chance to see baiji? Environ Sci Pollut Res Int 13:418-424

Wang D, Turvey ST, Zhao X, Mei Z (2013) Neophocaena asiaeorientalis ssp. asiaeorientalis. The IUCN Red List of Threatened Species 2013:e.T43205774A45893487. http://dx.doi.org/10.2305/IUCN.UK.2013-1.RLTS. T43205774A45893487.en (accessed 10 November 2018)

Wright RK, Davis JH (1980) The investigation of electrical deaths: a report of 220 fatalities. J Forensic Sci 25: 514-521

WWF \& FiA (Fisheries Administration of the Ministry of

Editorial responsibility: Jeff Mangel (Guest Editor),

Lima, Peru
Agriculture, Forestry, and Fisheries) (2014) Workshop on the conservation of Irrawaddy dolphins in the Mekong River. www.iucn-csg.org/wp-content/uploads/ 2010/03/Report-of-the-2017-International-Workshop-onthe-Conservation-of-Irrawaddy-Dolphins-in-the-MekongRiver.pdf

WWF \& FiA (2017) Report of the International workshop on the conservation of Irrawaddy dolphins in the Mekong River, Kratie, Cambodia. www.iucn-csg.org/wp-content/uploads/ 2010/03/Report-of-the-2017-International-Workshop-on-theConservation-of-Irrawaddy-Dolphins-in-the-MekongRiver.pdf

Z Zhang X, Wang D, Liu R, Wei Z, Hua Y and others (2003) The Yangtze River dolphin or baiji (Lipotes vexillifer): population status and conservation issues in the Yangtze River, China. Aquat Conserv 13:51-64

Zhou K, Li Y (1989) Status and aspects of the ecology and behavior of the baiji, Lipotes vexillifer, in the lower Yangtze River. In: Perrin W, Brownell R, Zhou K, Liu J (eds) Biology and conservation of the river dolphins. World Conservation Union, Gland, p 86-91

Zhou K, Wang X (1994) Brief review of passive fishing gear and incidental catches of small cetaceans in Chinese waters. Rep Int Whal Comm Spec Issue 15:347-354

Zhou K, Zhang X (1991) Baiji: the Yangtze River dolphin and other endangered animals in China. Yilin Press, Nanjing

Zhou K, Sun J, Gao A, Würsig B (1998) Baiji (Lipotes vexillifer) in the lower Yangtze River: movements, numbers, threats and conservation needs. Aquat Mamm 24:123-132

Submitted: January 15, 2019; Accepted: April 17, 2019

Proofs received from author(s): July 4, 2019 